\title{
From Scope to Process
}

\section{The Evolution of Checks on Presidential Power in US Foreign Relations Law}

\author{
Jean Galbraith
}

A core challenge for foreign relations law - as with all public law - is how to constrain decision-makers and yet enable them to be effective. Power and flexibility are necessary to successful governance, but they are also the keys to despotism. The challenge of this conundrum underlies much of political theory and constitutional law.

In the United States, the original solution was an innovative distribution of powers between various branches of government. The Framers of the US Constitution gave certain powers to Congress, as set forth in the Constitution's Article I, and certain powers to the President, as set forth in its Article II. ${ }^{1}$ A third branch - the courts - could resolve constitutional disputes between these branches in appropriate cases. By disaggregating government into separate strands, the Framers believed that these "constituent parts may, by their mutual relations, be the means of keeping each other in their proper places'. ${ }^{2}$

Over time, however, this distribution of powers has changed with respect to foreign affairs. The core story, often told, is of the rise of presidential power. ${ }^{3}$ The original constitutional design sought to require congressional approval for nondefensive uses of force, Senate approval for important international agreements, congressional control over international commerce, and arguably a general principle of congressional control with respect to foreign affairs. Yet in today's world, the President has considerable authority to initiate non-defensive uses of force,

1 See US Constitution, arts. I and II.

2 James Madison, 'Federalist No. 51', in Clinton Rossiter (ed.), The Federalist Papers (New York: New American Library, 1961).

3 For two of many such accounts, see Arthur M. Schlesinger, Jr., The Imperial Presidency (Boston: Houghton Mifflin, 1973); Eric A. Posner and Adrian Vermeule, The Executive Unbound: After the Madisonian Republic (Oxford: Oxford University Press, 2010). 
make international agreements without Senate approval, act in relation to foreign commerce without the assent of the current Congress, and more generally assert the 'lion's share' of control over foreign affairs. ${ }^{4}$

As the scope of the President's power has grown, however, it has also become subject to more process-based requirements. Transparency and regularity are now often expected and not infrequently mandated with respect to uses of executive power related to foreign affairs. These requirements do not stem from the US Constitution but rather from a web of diffuse sources, including US congressional law, US executive branch practice, and various aspects of international law. This new set of constraints serves to some degree as a substitute for the original constitutional constraints.

This book chapter describes these twin developments in relation to presidential foreign affairs power - the erosion of scope-based checks and the rise of process-based checks. It argues that international law has played a role in both developments. In closing, it considers the extent to the changes described here may have relevance for the practice of other nations.

Throughout the chapter, the terms 'scope-based' and 'process-based' are used in a distinct and perhaps idiosyncratic way. They are used not in relation to the entire power of the federal government, but rather more narrowly in relation to the power of the President and the executive branch that works under him or her. The term 'scope-based' (and related terms) refer to what the President has the legal authority to do as a matter of domestic law amid congressional silence. The term 'process-based' (and related terms) refer to how this legal authority is to be exercised. By way of example, the question of whether the President has the domestic legal authority to bomb Syrian government facilities in response to Syria's use of chemical weapons against its own citizens is treated here as an issue of scope. By contrast, the question of whether, with respect to such a use of force, the President has satisfied any legal requirements relating to notice, consultation, reporting, and reasoned decision-making is treated as an issue of process. Distinctions between scope and process are always complicated at the margins, but the two concepts nonetheless serve as useful frames for thinking about the scope of executive power. ${ }^{5}$

4 Edward S. Corwin, The President: Office and Powers, 1787-1948, 3rd ed. (New York: New York University Press, 1948), p. 208.

5 The use of these concepts inevitably depends on one's vantage point. Because I focus here on the power of the executive branch rather than on the power of the federal government as a whole, I consider the President's power to use force to be a 'scope-based' issue - a question of what the President can do unilaterally. If I were focusing on the power of the federal government as a whole, I might consider the overall extent of the US government's power to use force under the US Constitution and international law to be a 'scope-based' issue but the question of how power is divided within the various branches of the federal government to be a 'process-based' issue. And if 


\section{THE EROSION OF SCOPE-BASED CONSTITUTIONAL CHECKS ON THE PRESIDENT'S FOREIGN RELATIONS POWERS}

Perhaps inevitably, consideration of US foreign relations law starts with the US Constitution. Its Framers sought to provide the US government with a full panoply of foreign affairs powers, but they spread control over these powers between Congress and the President. In the years since, however, the scope of presidential power has increased. The President now considers himself or herself able as matter of scope to undertake a vast swath of decision-making related to US foreign affairs without the affirmative approval of Congress.

By way of illustration, consider the following four foreign affairs powers:

- Uses of Force. The text of the Constitution allocates to Congress numerous powers related to war, including the power to declare war, while making the President commander-in-chief. ${ }^{6}$ Over time, however, the President has come to assert more and more concurrent power with respect to the initiation of uses of force. ${ }^{7}$ The US executive branch still recognizes that a full-scale war likely requires congressional authorization, but many substantial uses of force in the twentieth and twenty-first centuries have been initiated without congressional authorization. ${ }^{8}$

- International Agreements. The text of the Constitution provides that the President shall have power to make treaties with the advice and consent of two-thirds of the Senate. ${ }^{9}$ While some agreements do still go through this process, in practice Presidents have also come to make international agreements, including very important ones, through several other alternative processes. Some of these agreements are made with clear congressional authorization, but others are made by the executive branch acting either alone or in reliance on a vague statutory

I were focused on the power of the United States rather than of its government, I might consider it a 'process-based' issue whether the US government had a particular power or instead would need a constitutional amendment to have that power. My focus throughout this chapter, however, is on the power of the presidency.

6 US Constitution, arts. I \& 8, cll. 11-14 and II \& 2, cl.1.

7 For a discussion of this development and of its relationships to international law on the use of force, see generally Curtis A. Bradley and Jean Galbraith, 'Presidential War Powers as an Interactive Dynamic: International Law, Domestic Law, and Practice-Based Legal Change' (2016) 91 New York University Law Review 689.

8 For a recent articulation of the legal views of the executive branch on this issue, see Steven A. Engel, Assistant Attorney General, Office of Legal Counsel, 'April 2018 Airstrikes Against Syrian Chemical-Weapons Facilities: Memorandum Opinion for the Counsel to the President', US Department of Justice, May 31, 2018, www.justice.gov/olc/opinion/file/1067551 /download, accessed April 3, 2020.

9 US Constitution, art. II $\mathbb{2} 2$, cl. 2. 
provision. ${ }^{10}$ These agreements may not have the power to alter US domestic law, but they can serve as binding international commitments on the part of the United States.

- Commerce. The text of the Constitution provides Congress with the authority to regulate foreign commerce. ${ }^{11}$ Unlike with respect to uses of force and international agreements, the President typically does not assert independent constitutional authority over foreign commerce. Nonetheless, the President has very substantial control in practice over the regulation of foreign commerce, as existing congressional statutes delegate considerable authority in this domain to the President. The imposition of the various tariffs by the Trump administration are recent examples. ${ }^{12}$

- Overall Control over Foreign Affairs. The text of the Constitution does not set forth a general foreign affairs power. It is at best debatable whether the text of the Constitution should be read as granting such a power to the President, and indeed there is considerable evidence from the timing of the Framing suggesting that if such a power exists, it should lie with Congress. ${ }^{13}$ Nonetheless, such a power is often asserted by the executive branch to lie with the President. ${ }^{14}$

10 See generally Jean Galbraith, 'From Treaties to International Commitments: The Changing Landscape of Foreign Relations Law' (2017) 84 University of Chicago Law Review 1675 (discussing the development of these agreements and the extent to which they are subject to separation-of-powers constraints).

"II Constitution, art. I $\$ 8$, cl. 3 .

12 See Timothy Meyer and Ganesh Sitaraman, 'The Power To Declare Trade War', Lawfare Blog, March 23, 2018, www.lawfareblog.com/power-declare-trade-war, accessed April 3, 2020 (describing how vaguely worded preexisting statutes have served as authorizations for these tariffs).

13 This evidence includes Congress's constitutional power to make laws 'necessary and proper' for executing the constitutional powers of the US government, US Constitution, art. I $\$ 8$, cl. 18; the President's obligation to 'take care that the laws be faithfully executed', US Constitution, art. II $\int 3$; and the broader backdrop underlying the concept of executive power at the time, see generally Julian Davis Mortenson, 'Article II Vests Executive Power, Not the Royal Prerogative' (2019) 119 Columbia Law Review 1169.

14 See Charles J. Cooper, Assistant Attorney General, Office of Legal Counsel, 'Memorandum Opinion for the Attorney General Regarding the President's Compliance with the "Timely Notification" Requirement of Section 501(b) of the National Security Act', US Department of Justice, December 17, 1986, www.justice.gov/file/23891/download, accessed April 3, 2020 (concluding that the President has 'plenary authority to represent the United States and to pursue its interests outside the borders of the country, subject only to limits specifically set forth in the Constitution itself and to such statutory limitations as the Constitution permits Congress to impose by exercising one of its enumerated powers'); see also, e.g., Stephen E. Boyd, Assistant Attorney General, Office of Legislative Affairs, Letter to Eliot L. Engel, 
The rise of the President's foreign affairs powers undoubtedly has multiple causes. In a famous concurring opinion written during the 1950s, Supreme Court Justice Robert Jackson pointed to the political prestige of the President, the rise of the party system, and the perceived need to address urgent situations over time as likely causes for 'the gap that exists between the President's paper powers and his real powers. ${ }^{15}$

The structure of the international legal system may itself have contributed to the rise in the President's foreign affairs powers vis-à-vis Congress. ${ }^{16}$ At various points in time Presidents or their lwyers have pointed to international law in justifying claims of presidential power. With respect to war powers, for example, executive branch actors drew on nineteenth-century international legal conceptions of sovereignty in defending a unilateral presidential authority to use force in the protection of citizens abroad. ${ }^{17}$ Also in the nineteenth and later in the twentieth century, Presidents and their lawyers pointed to international law in arguing for a narrow construction of what amounts to a 'war' requiring congressional approval. ${ }^{18}$ With respect to international agreements, executive branch decision-makers also sometimes drew on international legal principles in defending the domestic constitutional right of the President to enter into these agreements without the advice and consent of the Senate. ${ }^{19}$

That the President's scope-based foreign affairs powers have grown vis-à-vis Congress does not mean that these powers are without scope-based limits.

Chairman, House Committee on Foreign Affairs, US Department of Justice, May 7, 2019, www .justice.gov/ola/page/file/1160886/download, accessed April 3, 2020 (citing this 1986 memorandum in claiming that draft legislation would be unconstitutional to the extent that it 'require[d] the President to adopt a [particular] foreign policy').

15 Youngstown Sheet \& Tube Co. v. Sawyer, 343 US 579, 651-54 (1952) (Jackson, J., concurring).

16 For an elaboration of this argument, see generally Jean Galbraith, 'International Law and the Domestic Separation of Powers' (2013) 99 Virginia Law Review 987.

17 Bradley and Galbraith, 'Presidential War Powers', 712-18 (giving examples).

18 Galbraith, 'International Law and the Domestic Separation of Powers', 1021-23, 1024-25 (giving examples).

19 Galbraith, 'International Law and the Domestic Separation of Powers', 1028-33. Similarly, executive branch lawyers pointed at times to international legal practice in justifying the unilateral domestic constitutional power of the President to terminate treaties made with the advice and consent of the Senate. See, e.g., Memorandum from Green Haywood Hackworth, Legal Advisor of the Department of State, Abrogation of Treaties (27 January 1936), quoted in (1943) 5 Digest of International Law 328 ('A contention that the action of the President in denouncing a treaty must be submitted to ... the Senate ... would seem to be questionable for the reason that when the President has given notice of the desire of this Government to terminate a treaty, the failure of ... the Senate to approve does not alter the situation ... [as] the foreign government may decline to accept a withdrawal of such notice'). 
There remain some situations in which the President needs congressional approval in the domain of foreign affairs, although the contours of these situations are often ill-defined. And while preexisting congressional law often serves to authorize presidential action with respect to foreign affairs as in the example of tariffs - there are also some statutes that place limits on the President's foreign affairs powers. ${ }^{20}$ Additionally - and importantly - there are limits on presidential power separate and apart from those grounded in the separation of powers. The President is also subject to limits stemming from international law and from constitutional protections for individual rights. ${ }^{21}$ For all these limits, however, the scope of presidential power remains vast with respect to foreign affairs.

\section{THE RISE OF PROCESS-BASED CHECKS ON PRESIDENTIAL POWER}

There is a corollary to the rise of the President's scope-based powers. This is the development of more process-based rules with respect to how the President should exercise foreign affairs powers. These rules are not grounded in US constitutional law, but rather come from congressional statutes, executive branch regulations, and broader principles of public law manifested through the practice of the US administrative state. Significantly, some of these process-based limits also stem from international law or more generally from the way in which the US executive branch interfaces with the international legal system. Although the limits imposed by these process-based checks are different in nature from scopebased checks, they nonetheless have a constraining effect on presidential power.

20 One notable example is the provision in the War Powers Resolution requiring that the President withdraw US armed forces from hostilities after sixty days unless the President has received affirmative approval from Congress to continue the hostilities. 50 USC $\$ 1544$ (b). Some administrations have questioned the constitutionality of this provision and even more administrations have interpreted it narrowly. Nonetheless, it is thought to have had some constraining effect on practice. David P. Auerswald and Peter F. Cowhey, 'Ballotbox Diplomacy: The War Powers Resolution and the Use of Force' (1997) 41 International Studies Quarterly 505.

${ }^{21}$ The enforcement of these limits can be a challenge. The United States has pulled away from the jurisdiction of international courts, and US domestic courts have imposed various barriers to review over claims tied to foreign affairs, particularly ones rooted in international law. See, e.g., Medellin v. Texas, $55^{2}$ US 491 (2008) (holding that certain types of international treaty obligations require congressional implementing legislation in order to give rise to domestic legal claims enforceable by the federal courts). 


\section{A Process-Based Checks Grounded in US Domestic Law and Practice}

The Framers of the US Constitution were not solely interested in deciding who had the power to do what. They also had an interest in how power was exercised. They were conscious of the values of transparency and orderly process, though recognizing that aspects of some foreign affairs might benefit from secrecy. This consciousness, however, did not manifest itself in the form of procedural rules set out for the executive branch about how to conduct its business, including its foreign policy. What few procedural rules there were instead were aimed at Congress, including a clause encouraging Congress to establish Rules of Proceedings and another clause requiring it to publish Journals of Proceedings. ${ }^{22}$ The issue of process rules for the executive branch was not one which they addressed in the text of the Constitution, other than some thin provisions about consultation with ministers and with Congress that left considerable room for presidential discretion. ${ }^{23}$

The absence of process-based requirements on the executive branch in the text of the US Constitution does not mean that such requirements are absent from US foreign relations law. Rather, these process-based requirements exist, but they are deemed to be nonconstitutional in nature.

Congress is one important source of process-based limits on the President's foreign affairs powers. The War Powers Resolution passed by Congress in the 1970s requires the President to meet certain consultation and reporting requirements with respect to the initiation of hostilities. ${ }^{24}$ The CaseZablocki Act similarly sets out various process-based requirements for the executive branch to follow with respect to international agreements that are not made through the process set out in the Constitution's Treaty Clause, including a reporting requirement. ${ }^{25}$ Both of these statutes were passed against

22 US Constitution, art. I $\int 5$, cll. 2 and 3 ('Each House may determine the Rules of its Proceedings ... Each House shall keep a Journal of its Proceedings, and from time to time publish the same, excepting such Parts as may in their Judgment require Secrecy').

23 US Constitution, art. II $\$ 2$, cl. 1 ('[The President] may require the Opinion, in writing, of the principal Officer in each of the executive Departments, upon any Subject relating to the Duties of their respective Offices') and $\mathbb{3}$ ('He shall from time to time give to the Congress information of the State of the Union').

2450 USC $\$ 1542$ ("The President in every possible instance shall consult with Congress before introducing United States Armed Forces into hostilities ... and after every such introduction shall consult regularly with Congress until United States Armed Forces are no longer engaged in hostilities'); 50 USC $\$ 1543$ (requiring the President to give notice to Congress within fortyeight hours of various actions, including the introduction of US troops into hostilities, and to subsequently provide periodic updates to Congress).

251 USC $\int 112 \mathrm{~b}$ (requiring that the text of such agreements be transmitted to Congress or the relevant congressional committee within sixty days of their entry into force and imposing other procedural requirement, including that 'an international agreement may not be signed or 
a backdrop of congressional recognition that the President's foreign affairs powers had grown in scope since the time of the Framing. They therefore reflect, at least in part, a deliberate choice to make process-based limits available as a partial substitute for now eroded limits on scope. Similarly, in the trade context, trade statutes delegating power tend to fold in some process requirements. ${ }^{26}$ In these statutes, Congress is both providing the executive branch with increased scope to exercise power and setting out requirements with respect to how it is to be exercised. Finally, separate and apart from statutes, the 'soft' oversight powers that congressional committees have in terms of opening investigations and holding hearings can serve as processrelated incentives for thoughtful executive branch decision-making. ${ }^{27}$

A second important source of process-based requirements is the executive branch itself. The President is the head of an enormous bureaucracy (or perhaps more aptly of many enormous bureaucracies). In the foreign affairs decision-making space, as with domestic affairs, the executive branch has developed numerous internal rules and procedures for how its affairs are to be conducted. Some such processes are set forth in executive orders issued by the President, which typically last across administrations in the absence of repeal. ${ }^{28}$ Others lie within specific agencies. With respect to international agreements, for example, the State Department has long-standing regulations addressing the process by which these are to be made. ${ }^{29}$

The importance of regular process can potentially be amplified by the expectations of US domestic courts. As mentioned earlier, US courts have

otherwise concluded on behalf of the United States without prior consultation of the Secretary of State').

26 By way of example, the steel and aluminum tariffs imposed by the Trump administration on many nations were done pursuant to a statute that requires the US Secretary of Commerce to follow certain procedural steps in investigating whether to recommend the imposition of tariffs. See 19 USC $\int 1862$ (providing, among other things, that the Secretary of Commerce is to undertake interagency consultations as appropriate and if it is appropriate and after reasonable notice, hold public hearings or otherwise afford interested parties an opportunity to present information and advice relevant to such investigation').

27 See generally Josh Chafetz, 'Congress's Constitution' (2012) 160 University of Pennsylvania Law Review 715 (discussing these oversight powers).

28 By way of example, Executive Order 12,333 from 1981 continues to provide a regulatory framework for the conduct of US intelligence activities related to foreign affairs. See Executive Order 12333, 46 Fed. Reg. 59941 (1981). For a broader discussion of US intelligence practice, see Samuel J. Rascoff, 'Presidential Intelligence' (2016) 129 Harvard Law Review 633; see also at $6_{37}$ (describing 'presidential intelligence' as 'the White House's sustained, routinized, and process-driven governance of American spying').

29 Known as the C-175 Procedure, these regulations can be found at 11 FAM $\iiint_{720-27}$. The original C-175 procedure was promulgated in the 1950s. See US Department of State Circular No. 175 of 13 December 1955, in (1956) 50 AJIL 784 . 
developed a variety of doctrines related to jurisdiction and justiciability that can prevent them from reaching the merits of cases, and these doctrines can have particular power in cases related to foreign affairs. Where courts do have jurisdiction, however, they may be open to claims of procedural irregularity or pretextual decision-making. The fast-and-loose approach to procedure that characterized so much of the Trump administration was plainly a source of concern to many judges, even though one of its most dubious decisions was upheld by a closely divided Supreme Court. ${ }^{30}$

\section{B Process-Based Checks Grounded in the Interface with International Law}

The international legal system itself provides some process-based checks as well. So much of foreign relations law is about engagement through international organizations. With engagement through these systems comes acceptance of their process-based requirements. This is another way through which certain procedural norms, including transparency, can be brought to bear on the US executive branch.

One set of such process-based checks is tied to participation in the ordinary business of an international organization. While plenty of diplomacy is carried out in back rooms, various international legal regimes incorporate forms of transparency into their operating procedures. To give a simple example, the US executive branch cannot unilaterally keep all observers out of a major UN conference. ${ }^{31}$ More generally, to the extent that international legal regimes are premised around open dialogue, the executive branch must engage in such dialogue in order to act effectively through the regimes. ${ }^{32}$ Just as US executive

30 In Trumpv. Hawaii, 585 US _, 138 S Ct 2392 (2018) the Supreme Court upheld the travel ban imposed by the Trump administration on immigrants and visitors seeking to enter the United States from several Muslim-majority countries by a 5-4 vote. In dissent, Justice Sotomayor aptly argued that evidence of President Trump's animus towards Muslims, combined with the shaky administrative process by which the travel ban was imposed, would lead 'a reasonable observer [to] conclude that the Proclamation was driven primarily by anti-Muslim animus, rather than by the Government's asserted national-security justifications'. Trump v. Hawaii, at 2438-44 (Sotomayor, J., dissenting).

${ }^{31}$ For discussion of the process by which observer status is granted, see 'Formal Procedures for Granting Observer Status' (2008) UN Juridical Yearbook 439 ('In practice, the General Assembly has adopted resolutions granting observer status to various organizations and entities').

32 Constraints through dialogue can exist in bilateral relations as well, although this dialogue is presumably less likely to be conducted in the public sphere. See Ashley Deeks, 'Checks and Balances from Abroad' (2016) 83 University of Chicago Law Review 65, 68 (observing that if 'one recognizes that US national security increasingly relies on relationships with foreign partners, then the idea that the executive responds to foreign critiques and concerns to enable ongoing partnerships has bite'). 
branch actors are aware of the prospect of congressional oversight, so too are they aware of the prospect of international criticism. If the President chooses to invade Grenada, for example, his representatives must be prepared to defend this choice to the Security Council - and to cast a public veto of a resolution condemning this action. ${ }^{33}$ Although the executive branch representatives are nominally defending the decisions of the United States, in practice the decisions they are defending are often ones made specifically by the President as opposed to ones that are also explicitly authorized by Congress.

A further set of process-based checks could potentially stem from the way in which international legal regimes use reporting and review mechanisms as enforcement devices. Partly because of the difficulty in getting states to agree to other remedies, treaty regimes rely heavily on reporting requirements. This is true with regard to many substantive areas of international law and especially in the human rights context. ${ }^{34}$ The reporting process can both shine a light on state behavior and serve as a focal point for international and domestic pressure aimed at particular state polices. ${ }^{35}$ Because of the relative insularity of the United States and the various other ways in which information related to the United States is transparent, it is unclear how much additional transparency these reporting requirements bring to US practice. But at least in

33 See Richard Bernstein, 'U.S. Vetoes U.N. Resolution "Deploring” Grenada Invasion', New York Times, October 29, 1983, www.nytimes.com/1983/10/29/world/us-vetoes-unresolution-deploring-grenada-invasion.html, accessed April 3, 2020 (noting the 11-1 vote, with 3 abstentions and noting that "[a]mong the $6_{3}$ countries that requested to speak in the Security Council debate, only a small number of Caribbean nations defended the invasion ... [and n] early all the rest condemned it with varying degrees of harshness').

34 For a general discussion, see Abram Chayes and Antonia Handler Chayes, The New Sovereignty: Compliance with International Regulatory Agreements (Cambridge, MA: Harvard University Press, 1998), p. 154 (describing the role of reporting requirements and noting that their 'incidence ... is so high that they seem to be included almost pro forma in many [international] agreements, with little concern about cost or implementing capacity'). For some of the considerable literature on human rights reporting requirements, see, e.g., Philip Alston and James Crawford (eds.), The Future of UN Human Rights Treaty Monitoring (Cambridge: Cambridge University Press, 2000); Gudmundur Alfredsson, Jonas Grimheden, and Bertrand G. Ramcharan (eds.), International Human Rights Monitoring Mechanisms: Essays in Honour of Jakob Th. Möller (Leiden: Martinus Nijhoff Publishers, 2009); Jasper Krommendijk, The Domestic Impact and Effectiveness of the Process of State Reporting under UN Human Rights Treaties in the Netherlands, New Zealand and Finland: Paper-pushing or policy prompting? (Cambridge: Intersentia, 2014).

35 See Cosette D. Creamer and Beth A. Simmons, "The Dynamic Impact of Periodic Review on Women's Rights' (2018) 81 Law and Contemporary Problems 31 (finding that 'self-reporting [by states] has a significant positive effect on women's rights' and considering the mechanisms that might underly such an effect). 
theory, they are another way in which the executive branch must publicly account for its choices - and more generally for US behavior.

\section{Presidential Power in an Age of Process-Based Checks}

As Congress's scope-based checks on presidential power have dwindled, process-based checks have grown. It is difficult to measure the practical effect of this trade-off. Process-based checks are not as formally robust as scope-based checks. They do not serve as an absolute bar to action, but rather go to how the decision to undertake this action should be reached and to what extent the action and the related decision-making process should be done in a way that is transparent and therefore subject to evaluation and criticism. Are these lighter process-based checks more or less normatively desirable than robust scopebased checks? The answer may depend upon the particular context. It is possible, for example, to be supportive of the current system with respect to the making of international agreements yet more skeptical about it with respect to uses of force.

The presidency of Donald Trump tested the power of process-based checks. Executive branch lawyers in the Trump administration took robust positions on the scope of presidential powers. This was true both with respect to the President's constitutional powers and with respect to how broadly to read preexisting delegations in congressional statutes. At the same time, the Trump administration showed little respect for orderly internal process within the executive branch..$^{36}$ Yet the Trump administration remained subject to process constraints in other ways, including from Congress. With respect to the use of force, for example, Congress lacked the votes necessary to override a presidential veto and impose scope-based checks on presidential power. ${ }^{37}$ But in 2018 and 2019 Congress legislated to incorporate stronger reporting requirements with respect to the legal and policy justifications offered by the

${ }^{36}$ See, e.g., W. Neil Eggleston and Amanda Elbogen, "The Trump Administration and the Breakdown of Intra-Executive Legal Process' (2018) 127 Yale Law Journal Forum 825, 847 (discussing these challenges, including the ones that arise when 'a President wakes up one morning and decides to change a policy by tweet without involving [the] extensive apparatus' of 'a full array of experts at the National Security Council, the State Department, the Central Intelligence Agency, the Department of Homeland Security, the Department of Justice and other agencies').

37 See Jean Galbraith, 'Contemporary Practice of the United States: U.S. Drone Strike in Iraq Kills Iranian Military Leader Qasem Soleimani' (2020) 114 AJIL 313, 320 (describing how both the House and the Senate passed resolutions stating that the executive branch lacked the authority to use force aggressively against Iran, but that there were not enough votes for these resolutions to overcome a presidential veto). 
executive branch for uses of force. ${ }^{38}$ It remains to be seen what long-term effects, if any, such process-based requirements have on the outcomes of presidential decisions with respect to foreign relations.

\section{SCOPE, PROCESS, AND COMPARATIVE PRACTICE}

US foreign relations law offers a unique set of bridges and boundaries. With its presidential system of government, eighteenth-century constitutional text, and distinctive role on the international stage, the United States has developed a set of foreign relations law practices that are all its own and that are often impenetrable. For the lay person, the well-educated lawyer, the foreign practitioner - maybe everyone but the expert in the specific field, US foreign relations law is excruciatingly hard to understand. Indeed, one of the ironies of the shift from scope-based limits to process-based limits described above is that it is untransparent to most observers.

Other countries undoubtedly strike different balances between scope-based checks and process-based checks on the power of the executive. In the United Kingdom, for example, there has been a recent rise in scope-based checks on executive power, including the developing constitutional convention requiring parliamentary authorization for certain uses of force and the UK Supreme Court's decision that parliamentary approval would be required for the treaty withdrawal underlying Brexit. ${ }^{39}$ In Germany, the Basic Law was amended in the 1990 such that the new Article 23 set forth both scope-based and processbased limits on executive branch decision-making with respect to German participation with the European Union. ${ }^{40}$ These developments place

$3^{8}$ See Scott R. Anderson and Erica Newland, 'Why the Trump Administration May End up in Court Over War Powers Reporting', Lawfare Blog, February 28, 2020, www.lawfareblog.com /why-trump-administration-may-end-court-over-war-powers-reporting, accessed April 3, 2020 (describing these new requirements).

39 See, e.g., Katja S. Ziegler, "The Use of Military Force by the United Kingdom: The Evolution of Accountability', University of Leicester School of Law Research Paper No. 18-o9, December 12, 2018, https://papers.ssrn.com/sol3/papers.cfm?abstract_id=3300107, accessed April 3, 2020 (discussing the rising constitutional convention with respect to parliamentary approval for at least certain kinds of uses of force); R (Miller) v. Secretary of State for Exiting the European Union 2017 [UKSC] 5, www.bailii.org/uk/cases/UKSC/2017/5.html, accessed April 3, 2020 (concluding that parliamentary approval was necessary prior to the government's giving the requisite treaty notice of withdrawal from the Treaty on European Union); see also Curtis A. Bradley and Laurence R. Helfer, 'Treaty Exit in the United States: Insights from the United Kingdom or South Africa' (2018) 111 AJIL Unbound 428 (discussing not only the UK Supreme Court decision but also a similar decision reached by the High Court of South Africa).

40 German Basic Law, art. 23 (providing as translated, for example, that ' $[\mathrm{b}]$ efore participating in legislative acts of the European Union, the Federal Government shall provide the Bundestag with an opportunity to state its position' and setting out various ground rules regarding the 
constitutional limits on executive power in foreign affairs, unlike the US pattern of long-standing erosion of such limits.

Although the US trajectory of limits on executive power in foreign relations law may be distinctive to the United States, the impact of this trajectory has broader implications. The transition between the Obama administration and the Trump administration demonstrated the instability that can come from the combination of strong presidential foreign affairs powers and a polarized US electoral process. In the future, it is possible that the US Supreme Court will restore more scope-based checks on the President's foreign affairs powers or that Congress will reclaim some powers with respect to trade and other economic sanctions that it has delegated to the President. But unless and until that happens, continuity in US foreign relations practice will depend heavily on process-based constraints.

roles to be played by the Bundestag, Bundesrat, and Länder in the course of decision-making); see also BVerfG, Judgment of the Second Senate of 19 June 2012 - 2 BvE 4/11 -, www.bverfg.de le/es20120619_2bveooo411en.html, accessed April 3, 2020 (reading art. 23 broadly to apply to certain other international agreements closely connected with the European Union). 